Babikova, K., \& Bucek, J. (2019). A Model Replication with an Extension of Students' Perception of Prospective Employer Attractiveness. Journal of Competitiveness, 11(2), 5-21. https://doi.org/10.7441/ joc.2019.02.01

\title{
A MODEL REPLICATION WITH AN EXTENSION OF STUDENTS' PERCEPTION OF PROSPECTIVE EMPLOYER ATTRACTIVENESS
}

\section{- Kristina Babikova, Jakub Bucek}

\begin{abstract}
In the light of a long-term rising focus on human resources as the essential for a competitiveness of organizations, human resource management intersects with marketing to help firms attract and retain potential employees. The existing literature, mainly referred to as employer branding, has been concerned primarily with the identification of relevant elements of the proposition of employer value, while several authors have pointed out the need to focus on relative elements. Therefore, the present research attempts to replicate a model by Sivertzen et al. (2013) which investigates factors regarding employer branding strategies, and to verify whether the predominant view of relevant elements might or might not be considered inadequate. We have replicated the model with the extension of different industries, and the paradigm was tested on two larger samples compared to the original paper. An electronic questionnaire was distributed to computer science students (337 responses) and students of economics (290) at universities in the Czech Republic. The findings indicate that several employer attractiveness attributes could have a positive relation to corporate reputation. However, results differ between industries. The validation of the employer attractiveness scale resulted in dimensions which are different than those in the original study, with new dimensions featuring different indicators proposed. A positive relation was found between the use of social media and corporate reputation, the use of social media with the intention of applying for a job, as well as corporate reputation in terms of the intention of applying for a job.
\end{abstract}

Keywords: buman resources, employer branding, recruiting, employer attractiveness, corporate reputation, social media

JEL Classification: $M 1, M 3, M 5$

Received: October, 2018

1st Revision: March, 2019

Accepted: April, 2019

\section{INTRODUCTION}

A sustained competitive advantage is the ultimate goal of every company, but views on how to achieve this have changed over time. Since the 1990s the focus on human resources as a factor in a company's success has been increasing. The importance of human resources came with the resource-based view (RBV) theory rooted in the work of Penrose (1959) and the Harvard Design 
School (e.g. Andrews, 1971), later applied by Wernerfelt (1984) and spread further by Barney (1991). RBV transformed the thinking about strategic management and made available new strategic options for companies. This view emphasizes internal resources (as a shift from external) as a starting point for organizational success, and therefore as the resources which determine the sustained competitive advantage of a company (Barney, 1991). Therefore, both potential and existing employees were shifted from a position in which they needed to fight for allocations from a company budget (Wright et al, 2001) through the growing acceptance of the importance to the awareness of the need to integrate strategic steps into daily operations (Bergeron, 2004). For more than twenty years since, the existing general agreement that human capital can be a source of competitive advantage has been put into practice (Shaw \& Delery, 2001). Today, managing human capital as a part of strategic planning now is a must if the company wants to be or remain competitive and successful (Armstrong \& Taylor, 2014). The validity of this change of strategic view has been made clear by other reasons such as slightly changed labor market conditions as well as greater competition among companies for the best employees. In a situation in which there is a labor shortage, organizations can achieve a sustainable competitive advantage only if it can attract and retain qualified employees better than their competition can (Boxall, 1996; Guthridge et al, 2008). Companies are striving for strategies to "win the war" on the labor market, and for strategies regarding how to become or remain an attractive employer (Cascio \& Graham, 2016; Mahroum, 2000). Forming the prime approach for dealing with attraction, recruitment and retention challenges has become an intersection point between human resource management (HRM) and marketing, notably branding. Employer branding has been proposed as an effective way for companies to differentiate themselves from competitors and to gain a competitive advantage in the labor market effectively and strategically (Collins \& Stevens, 2002; Highhouse et al, 2003).

The focus of the literature on employer branding has led to a broad view of the phenomenon and has brought many other concepts, constructs and discourses (Theurer et al, 2018). Despite this fact or perhaps because of it, the field of employer branding still suffers from several gaps in knowledge and shortcomings as well as descriptions of the relationships between concepts and constructs. Employer branding is the process of building and promoting the unique aspects of a firm (Backhaus \& Tikoo, 2004), i.e. it is a part of the organization's strategy to attract and retain employees. However, one of the essential outcomes of branding is attractiveness itself. Organizational attractiveness is a subjective evaluation of the attractiveness of the brand (Lievens et al, 2007) by employees and is therefore influenced by many attributes which can be clustered into dimensions (Berthon et al, 2005). Those attributes and the ways to categorize them is what most prior employer branding research has dealt with (Theurer et al., 2018). Moreover, the long track from determining the important attributes of employer attractiveness to a state in which an organization is competitive on the labor market, and therefore competitive on the product or service market, requires considerable research.

Therefore, the purpose of the study is to present findings that contribute to the current knowledge on constructs connected with the employer branding research. Specifically, we present the replication results of an empirical evaluation of the model proposed by Sivertzen et al. (2013). Their model is trying to "identify potential employees' perception of an employer and their intentions to apply for a job" with the purpose of enabling organizations to focus their employer branding and recruitment actions thusly. Our replication presents an opportunity to confirm, falsify or re-evaluate the findings 
(Hubbard \& Armstrong, 1994; Hubbard \& Vetter, 1996), and therefore our study seeks to contribute to discussions in the field and to put forth new assumptions about employer branding. Replication studies are very rare, particularly in business and management sciences (van Witteloostuijn, 2016), with most journals not being welcoming to publishing replications. However, the importance of replication studies was well established in the last century, e.g. by well-known author Hubbard R. (1994; 1996; 1998), due to its important role in ensuring validity and reliability. The replication process protects the academic field from uncritical acceptance of empirical results and is essential especially for emerging fields (Singh, 2003), among which employer branding is considered. Replications should bring an opportunity to "separate chance findings from systematic results" (Harzing, 2016) and "to provide additional evidence that helps to build a cumulative body of knowledge" (Ethiraj et al, 2016). Therefore, we decided to work simultaneously and systematically on prior research along with replications. This paper conducts the replication with an extension, i.e. a duplication of an original paper to test conceptual relationships differently by slightly modifying aspects of the initial design (Hubbard \& Armstrong, 1994; Hubbard \& Vetter, 1996). The results of our use of the model are interlinked with the results of prior research in order to build bound knowledge in the employer branding field.

\section{THEORETICAL BACKGROUND}

Employer branding (EB) is primarily an intersection between human resource management and brand marketing (Ambler \& Barrow, 1996). It is an approach to promote an employer as different and desirable as compared to the competitors on a labor market (Lievens et al., 2007). This approach targets externally when recruiting potential employees, as well as internally to retain existing employees (Foster et al, 2010). This paper targets potential employees, specifically students with no or little work experience. In duplicating the model, we work with the definitions from the original paper. Recruiting is therefore defined as "organization activities that affect the number and type of applicants who apply for an open position” (Gatewood et al, 2011). Two main sides are included in recruitment situations, an organization and a potential employee. Employer branding is a set of organization's activities to build and promote the brand (Backhaus \& Tikoo, 2004). Nevertheless, the outputs of branding are dependent on the recipients, potential employees and their perceptions. Therefore, the field of employer branding is not only the intersection of HRM and marketing, but also the fields as vocational behavior (e.g. Turban, 2001; Turban et al, 1998), organizational behavior and psychology (e.g. Daniel \& José, 2010; Edwards, 2009) and many others. The model is constructed from outputs corresponding with the possible perception of potential employees and it proposes their relationships to test.

Often researched outcomes of employer branding are „organizational attractiveness” and „,corporate reputation". EB is supposed to be used to positively influence them, specifically to increase attractiveness and improve reputation of an organization. However, the relationship between attractiveness and reputation is not researched. Employer attractiveness is a subjective evaluation of attractiveness (Cable \& Turban, 2001; Collings \& Kanar, 2013) defined in our paper specifically as „the benefits potential employees see in employment in a specific organization“ (Berthon et al., 2005). To measure employer attractiveness, the scale was developed by Berthon et al. (2005) refined and extended from Ambler and Barrow's (1996) dimensions. The scale consists of 25 items divided 
into five dimensions. The dimensions assess the extent to which potential employees are attracted to an employer in a specific factor group (Berthon et al., 2005). Those are interest value, social value, economic value, development value and application value. Interest value is connected with innovative work practices and high-quality and innovative products and services. Social value dimension reflects the work environment and relationships in a workplace. Economic value assesses the extent of attractiveness coming with providing above-average salaries and other economic benefits, as well as promotional policy in a company. The fourth dimension is called development value and is connected with future job opportunities. Moreover, the last, but not least is the application value that reflects the possibility of using acquired knowledge in a consumer-oriented humanitarian environment of an organization. These and other characteristics which are socially constructed based on the organization's previous actions and prospects define corporate reputation (Sivertzen et al., 2013; Weigelt \& Camerer, 1988). The reputation does not only mean that an organization has qualities as an employer, but that an organization communicates these qualities to a range of key stakeholders (Hepburn, 2005). Organizations use a wide range of channels. However, the invention of the world wide web substantially changed the way to attract new employers. Internet enabled cost reduction (Borstorff et al., 2005) and the significant possibility of addressing passive job seekers as well (Cappelli, 2001). Moreover, along with the increasing popularity of social media over a few last years, many business sectors launched their social media's sites to promote their business (Fisher et al., 2014). There are predictions that human resources will increase their activities on social media as a part of a strategy to attract and retain employees (Chauhan et al, 2013). However, there are also threats and responses connected with using social media (Horn et al., 2015). Therefore, the essential part of the recruiting process, to arouse the intent to apply for a job in a particular company and its relationship with other constructs is questionable.

\section{RESEARCH OBJECTIVE, METHODOLOGY AND DATA}

In this section, first, the original study will be introduced, second, the present replication study will be introduced and compared with the original study, and then, a model will be explained and hypotheses formulated.

\section{Original study}

Sivertzen et al (2013) proposed the model to investigate the factors important when building successful employer branding strategies in organizations. „When employees are running employer branding campaigns, there is the need to know which factors actually lead to a good impression of the organization”. The proposed model was constructed (Fig. 1) from several parts. First of all, employer attractiveness (EmpAt) scale, developed by Berthon et al. (2005) and derived from Ambler and Barrow's (1996) dimensions, was tested. The scale consists of 25 items which were identified and divided into five dimensions - Interest Value (e.g. interest in product or service), Social Value (e.g. relation to colleagues), Economic Value (e.g. salary), Development Value (e.g. job opportunities) and Application Value (e.g. possibility to use employee's existing knowledge). Siverzen et al. (2013) further hypothesized whether these dimensions have a relation to a corporate reputation. To measures a corporate reputation, a scale developed by Turban et al. (1998) was used. It consists of four indicators (e.g. „I have heard a lot of good things about this firm”). To reach a goal of a model, to 
help organizations with recruiting strategies, the relationship between reputation and intentions to apply for a job were hypothesized (e.g. „I would accept a job offer from this company.”). Highhouse et al.'s (2003) scale with five items was used. Moreover, the use of social media was hypothesized as a moderating variable between corporate reputation and intention to apply for job variables. The use of social media was measured by a modified scale developed by Collins and Stevens (2002).

Sivertzen et al. (2013) empirically examined the proposed model by a survey procedure. The empirical results were based on primary data collected by the web-based questionnaire. The sample of participants was composed of Norwegian engineering students from three different Norwegian universities who were asked about three well-known Norwegian engineering firms. As Sivertzen et al. stated to justify their sampling, students are job seekers in the near future, and engineering is an industry where organizations have to compete to attract employees. Three companies were wellknown international companies as well as well-rated employers.

The original study was conducted on 184 students in total. To expand the sample, Sivertzen et al. included the results from three companies (answered by one student) as three answered questionnaires. This was stated to be done because of closely related means and standard deviations. Therefore, the original study counted with 366 answers for empirical research in total. The confirmatory factory analysis was conducted to fit the employer attractiveness scale, exploratory factor analysis to see the distribution of items among the dimensions. Ten EmpAt indicators were eliminated. Second, the main analysis of a model was assessed by computing and evaluating using Chi-Square test and its p-value, comparative fit index, normed fit index, non-normed fit index, adjusted goodness of fit index and the basis of root mean square approximation.

The variables of Social Value and Economic Value were removed from the model, as these did not have a significant relation to corporate reputation. Therefore, the validation of EmpAt scale ended up with altered dimensions compared to the original scale. Sivertzen et al. stated that Innovation, Psychological and Application Value-dimensions have positive relations to corporate reputation. The interaction effect between social media and reputation did not have a significant relation to intentions to apply for a job, however, social media as a recruiting tool indicate that they could be helpful when building a good reputation. Moreover, corporate reputation had a positive relationship with intentions to apply for a job, and as mentioned, social media did not influence the relationship.

\section{The present replication study}

Our replication study attempts to maximize similarities with the original study, however, we employed different data sets to evaluate the generalizability of earlier results (Singh, 2003), which we consider important when speaking about employer branding structure. This procedure is called replication with extension and tests conceptual relationships „differently by modifying certain aspects of the initial design. Our study did not make the changes in the model, used scales or any of the variables. The extension consists of different samples, specifically different ,industries“ as it is called in the original paper. The change should offer us the possibility of comparing perceptions of different segments.

Two samples of participants were chosen and therefore two groups of industry-related companies. First, information technology (IT) students were asked about three well-known Czech-based IT 
companies; Avast Software, Kiwi.com and Seznam.cz. Avast Software is a Czech multinational cybersecurity software company with more than 500 million users worldwide, Kiwi.com is a Czech multinational company providing a fare aggregator, metasearch engine and booking for airline tickets, well-known for their unique computing algorithms and Seznam.cz is a Czech search engine with more than 15 different web services and associated brands. Second, students of economics were asked about three well-known Czech-based companies related to economic studies; J\&T Bank, ČSOB (KBC) and Socialbakers. J\&T Bank is a Slovak bank institution operating on the Czech market from 1998, focusing on private banking and currently operating worldwide, $\check{C} \mathrm{SOB}(\mathrm{KBC})$ is one of the largest commercial banks operating in the Czech Republic as a member of KBC Group. Socialbakers is a Czech global social media analytics company. The choice of students as participants and choice of industries copied the logic of the original paper - students are job seekers in the near future and financial, marketing and information technologies are labor markets with a high degree of competitiveness between companies. Companies were, as well as in the original study, chosen as the attractive employers. We used the current results of the Universum survey - rating list of the employers in the Czech Republic (Universum, 2017). This strategy has brought the sample comparable to the original study. The data from the present study were collected in 2017/2018 school year. Students from Masaryk, Mendel and Brno University of Technology were approached primarily. The choice was influenced by the innovation character of the South Moravia region, which is remarkable by a considerable concentration of multinational companies and start-ups.

\section{Measurement of theoretical constructs}

The proposed model contains five constructs measured by the Likert scale. Employer attractiveness measured by Berthon's (2005) scale has 25 indicators and was measured by a seven-point Likert scale ranging from 1 (totally unimportant) to 7 (very important). Corporate reputation measured by Turban's (1998) scale has four indicators and was measured by a five-point Likert scale ranging from 1 (strongly disagree) to 5 (strongly agree). Use of social media scale was developed from Collins and Stevens's (2002) scale. The original scale was meant for use in general marketing and job vacancies, so it was adapted by Sivertzen et al. to the use of social media in employer branding. The final scale had four indicators and was measured by a five-point Likert scale ranging from 1 (strongly disagree) to 5 (strongly agree). Moreover, the last scale in the model is intentions to apply for a job. For its measuring, Highhouse et al.'s (2003) scale containing five indicators which were measured by a fivepoint Likert scale ranging from 1 (strongly disagree) to 5 (strongly agree) was used. Control variables such as gender, age, nationality, place of residence and work experience in a sector were used.

The proposed research model contains four testable hypotheses based on the literature review and are replicated from Sivertzen et al. (2013). Those are graphically illustrated in Fig. 1.

H1: Potential employees' perception of the five dimensions of employer attractiveness has a positive relation to their perception of a good corporate reputation.

H2: Potential employees' perception of employers' use of social media has a positive relation to a good corporate reputation.

H3: High corporate reputation has a positive relation to the potential employees' intention to apply for a job. 
H4: Potential employees' perception of employers' use of social media positively moderates the relationship between corporate reputation and potential employees' intention to apply for a job.

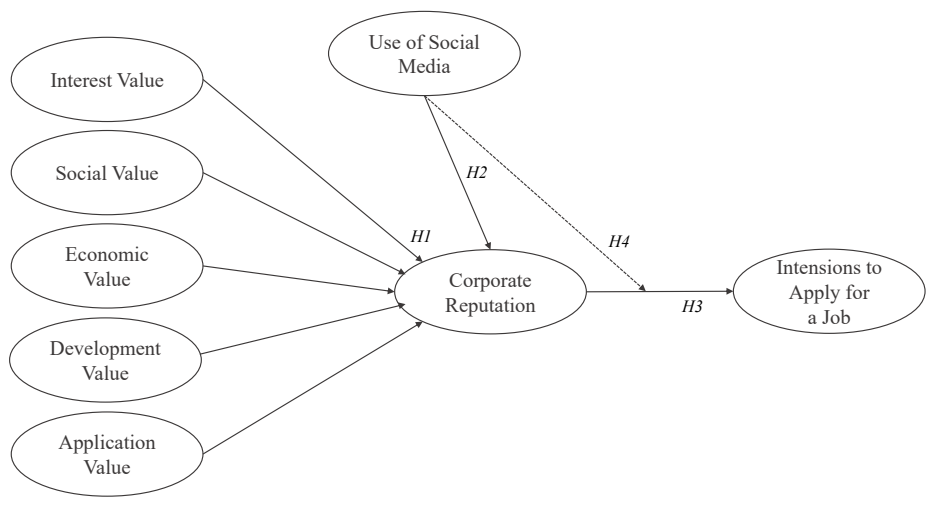

Fig. 1 - A proposed research model. Source: Original model by Sivertzen et al. (2013)

The proposed model was examined by a survey procedure. The empirical results were based on our primary data collected via the web-based questionnaire. These were distributed partly online, and subsequently, the questionnaires were distributed in a face-to-face mode by a peer-administered method in a self-administered computer process (Bowling, 2005). The questionnaire was available in English and Czech language. A professional translator, whose native language was Czech and whose focus is on business translations, translated the English versions into Czech. Both language versions were reviewed and pre-tested with a small group of 8 bilingual students to assess whether the questions are entirely understandable and could be answered by the target sample group. Despite this pre-test, we decided to exclude one of the indicators from EmpAt scale due to insufficient language clarity during the processing of collected data (q21). The questionnaire was developed, published and technically processed by professional on-line survey application Lime Survey. Responses collected through this application were exported into csv format and further processed and computed by $\mathrm{R}$ language and environment.

\section{RESULTS}

A total number of 189 students of economics answered our survey. Of the respondents, 78 (41\%) were male, and $111(59 \%)$ were female. The age of respondents ranges from 18 to 30 years old with mean slightly over 21 years old. Majority of the respondents are of Czech (143; $76 \%)$ and Slovak (40; $21 \%)$ nationality. There were $95(50 \%)$ with no work experience, $58(31 \%)$ had less than a year of work experience, and $36(19 \%)$ with more than a year of work experience. As the respondents could answer the survey for more than one company, some of them have done so. The 98 (52\%) of them answered the survey only for one company, 81 (43\%) answered the survey for two companies, and $10(5 \%)$ completed the survey for all companies. Almost everyone (188 out of 189 respondents) completed the survey for ČSOB, 86 (46\%) answered the questions for J\&T Banka, and only $16(8 \%)$ completed the survey for Socialbakers. This finding cannot be inputted to the order of occurrence 
of companies in the questionnaire as the order was following: Social Bakers, ČSOB, J\&T Banka. In total, we have 290 answers according to the original study process by Sivertzen et al. (2013).

A total number of 123 students of information technology answered our survey. Of the respondents, $85(69 \%)$ were male, and $35(31 \%)$ were female. The age of respondents ranges from 18 to 29 years old with mean exactly 22 years old. Majority of the respondents are of Czech (55; $45 \%)$ and Slovak $(67 ; 54 \%)$ nationality. There were $40(33 \%)$ with no work experience, $39(32 \%)$ had less than a year of work experience, and $44(36 \%)$ with more than a year of work experience. As the respondents could answer the survey for more than one company, some of them have done so. The $2(2 \%)$ of them answered the survey only for one company, 28 (23\%) answered the survey for two companies, and $93(76 \%)$ completed the survey for all companies. Almost everyone (121 out of 123 respondents) completed the survey for Seznam, 117 (95\%) answered the questions for Avast, and $99(80 \%)$ completed the survey for Kiwi.com. In total, we have 337 answers according to the original study process by Sivertzen et al. (2013). The groups of students are not homogeneous; therefore we have analyzed each group separately.

The structural equation modelling is a multivariate statistical framework that is used to model complex relationships between directly and indirectly observed (latent) variables. The overall fit of the models was evaluated using the Chi-Square test $\left(\chi^{\wedge} 2\right)$ that measures the deviance between an estimated and baseline model. We want to reject the null hypothesis of the $\mathrm{Ch}$ i-Square test. We also used alternative characteristics of fit: comparative fit index (CFI), Tucker-Lewis index (TLI), root mean square error of approximation (RMSEA) and standardized root mean square residual (SRMR). Hu \& Bentler (1999) suggested the following rules of thumb: CFI/TLI > 0.95, RMSEA < 0.05 and SRMR $<0.06$. Due to the nature of observed data (Likert scale), we have used polychoric correlation to compute the relationship between each pair of items.

Firstly, we conducted the confirmatory factor analysis (CFA) to evaluate the fit of the EmpAt scale. For both groups of students, the fit of the EmpAt scale was not sufficient. The CFA results for students of economics yielded in bad fit: $\chi^{2}(242)=1067.547$, CFI $=0.883$, TLI $=0.867$, RMSEA $=$ 0.109 . The CFA fit for students of information technology was even worse: $\chi^{2}(242)=1858.208$, CFI $=0.879$, TLI $=0.862$, RMSEA $=0.141$.

In the next step, we have tried to find other factors using an exploratory factor analysis (EFA) with varimax rotation that would satisfy the observed data. New factors and loading for both groups are presented in Tab. 1.

Tab. 1 - New factors and loadings for both groups. Source: own research

\begin{tabular}{|l|l|l|l|l|}
\hline \multirow{4}{*}{} & \multicolumn{2}{|l|}{ Students of economy } & \multicolumn{2}{l|}{ Students of IT } \\
\cline { 2 - 5 } & \multicolumn{2}{|l|}{ Question/Loadings } & \multicolumn{2}{l|}{ Question/Loadings } \\
\hline \multirow{5}{*}{ Factor 1 } & $\mathrm{q} 7$ & 0,535 & $\mathrm{q} 1$ & 0.586 \\
\cline { 2 - 5 } & $\mathrm{q} 8$ & 0.861 & $\mathrm{q} 5$ & 0.219 \\
\cline { 2 - 5 } & $\mathrm{q} 9$ & 0.632 & $\mathrm{q} 7$ & 0.591 \\
\cline { 2 - 5 } & $\mathrm{q} 23$ & 0.649 & $\mathrm{q} 8$ & 0.561 \\
\cline { 2 - 5 } & & & $\mathrm{q} 9$ & 0.786 \\
\cline { 2 - 5 } & & & $\mathrm{q} 19$ & 0.808 \\
\hline
\end{tabular}




\begin{tabular}{|c|c|c|c|c|}
\hline & & & q23 & 0.490 \\
\hline \multirow{4}{*}{ Factor 2} & q11 & 0.442 & q13 & 0.847 \\
\hline & q13 & 0.714 & q14 & 0.637 \\
\hline & q14 & 0.956 & q16 & 0.502 \\
\hline & & & q20 & 0.594 \\
\hline \multirow{4}{*}{ Factor 3} & q4 & 0.518 & q3 & 0.271 \\
\hline & q6 & 0.578 & $\mathrm{q} 4$ & 0.726 \\
\hline & q12 & 0.466 & q5 & 0.651 \\
\hline & & & q6 & 0.623 \\
\hline \multirow{3}{*}{ Factor 4} & q15 & 0.565 & q11 & 0.723 \\
\hline & q24 & 0.806 & q12 & 0.755 \\
\hline & q25 & 0.576 & q14 & 0.152 \\
\hline \multirow{3}{*}{ Factor 5} & $\mathrm{q} 2$ & 0.526 & q24 & 0.742 \\
\hline & q10 & 0.793 & q25 & 0.965 \\
\hline & q11 & 0.452 & & \\
\hline
\end{tabular}

The model for data from students of economics was tested by means of CFA: $\chi^{2}(79)=233.22, \mathrm{CFI}=$ $0.963, \mathrm{TLI}=0.951, \mathrm{RMSEA}=0.082$. The model for data from students of IT was tested by means of CFA: $\chi^{2}(121)=555.184, \mathrm{CFI}=0.951, \mathrm{TLI}=0.938, \mathrm{RMSEA}=0.103$.

The results of the regression for students of economics are presented in Tab. 2 and for students of IT in Tab. 3.

Tab. 2 - Regressions for students of economy. Source: own research

\begin{tabular}{|c|c|c|c|}
\hline & Estimate & Std. Err. & P-value \\
\hline \multicolumn{4}{|c|}{ Dependent Variable: Corporate Reputation } \\
\hline Factor 1 & 0.087 & 0.094 & 0.355 \\
\hline Factor 2 & -0.086 & 0.085 & 0.312 \\
\hline Factor 3 & 0.095 & 0.134 & 0.477 \\
\hline Factor 4 & 0.008 & 0.085 & 0.929 \\
\hline Factor 5 & -0.116 & 0.107 & 0.277 \\
\hline Use of Social Media & 0.375 & 0.068 & $<0.001$ \\
\hline \multicolumn{4}{|c|}{ Dependent Variable: Intentions to Apply for a Job } \\
\hline Corporate Reputation & 0.453 & 0.067 & $<0.001$ \\
\hline Use of Social Media & 0.245 & 0.068 & $<0.001$ \\
\hline Sex $(0=$ male, $1=$ female $)$ & 0.103 & 0.147 & 0.486 \\
\hline Age & -0.117 & 0.045 & 0.010 \\
\hline Work Experience $(0=$ none, $1=$ some $)$ & 0.131 & 0.151 & 0.388 \\
\hline Total Effect* & 0.415 & 0.071 & $<0.001$ \\
\hline
\end{tabular}

*Total Effect of Use of Social Media to Intension to Apply for a Job (direct and indirect effects) 
Fitting statistics: $\chi^{2}(437)=965.039, \mathrm{CFI}=0.970, \mathrm{TLI}=0.967, \mathrm{RMSEA}=0.065$.

Tab. 3 - Regressions for students of IT. Source: own research

\begin{tabular}{|c|c|c|c|}
\hline & Estimate & Std. Err. & P-value \\
\hline \multicolumn{4}{|c|}{ Dependent Variable: Corporate Reputation } \\
\hline Factor 1 & -0.153 & 0.080 & 0.055 \\
\hline Factor 2 & 0.338 & 0.069 & $<0.001$ \\
\hline Factor 3 & 0.104 & 0.099 & 0.294 \\
\hline Factor 4 & 0.076 & 0.086 & 0.380 \\
\hline Factor 5 & 0.000 & 0.065 & 0.997 \\
\hline Use of Social Media & 0.358 & 0.085 & $<0.001$ \\
\hline \multicolumn{4}{|c|}{ Dependent Variable: Intentions to Apply for a Job } \\
\hline Corporate Reputation & 0.841 & 0.080 & $<0.001$ \\
\hline Use of Social Media & 0.285 & 0.076 & $<0.001$ \\
\hline Sex $(0=$ male, $1=$ female $)$ & -0.479 & 0.200 & 0.016 \\
\hline Age & 0.022 & 0.043 & 0.612 \\
\hline Work Experience $(0=$ none, $1=$ some $)$ & -0.378 & 0.220 & 0.085 \\
\hline Total Effect* & 0.586 & 0.093 & $<0.001$ \\
\hline
\end{tabular}

*Total Effect of Use of Social Media to Intension to Apply for a Job (direct and indirect effects)

Fitting statistics: $\chi 2(530)=2143.649, \mathrm{CFI}=0.938, \mathrm{TLI}=0.931, \mathrm{RMSEA}=0.095$.

The overall model results of each data set are graphically illustrated in Fig. 2 for students of IT and in Fig. 3 for students of economics.

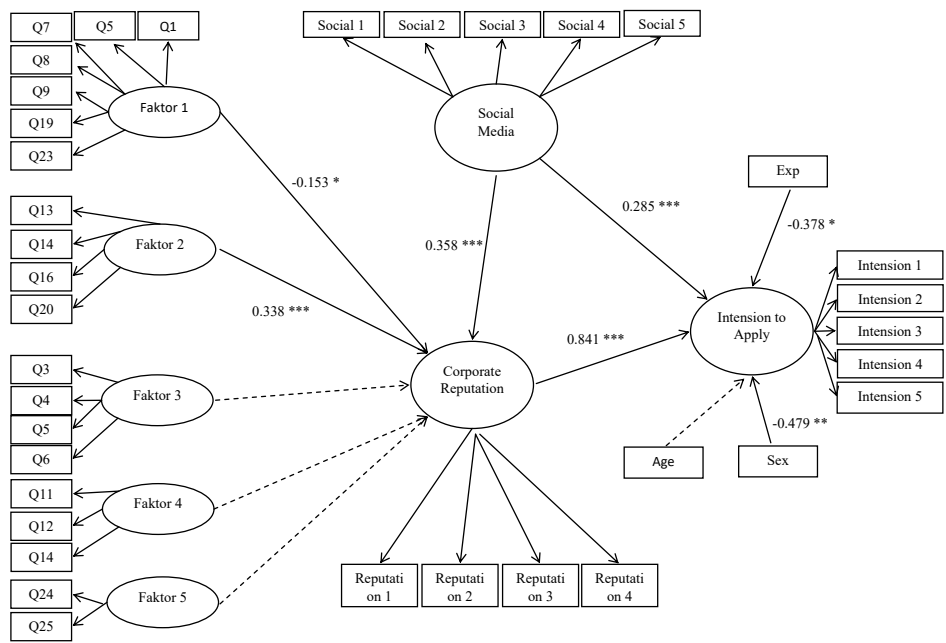

Fig. 2 - Overall results for the data set of students of IT. Source: own research 


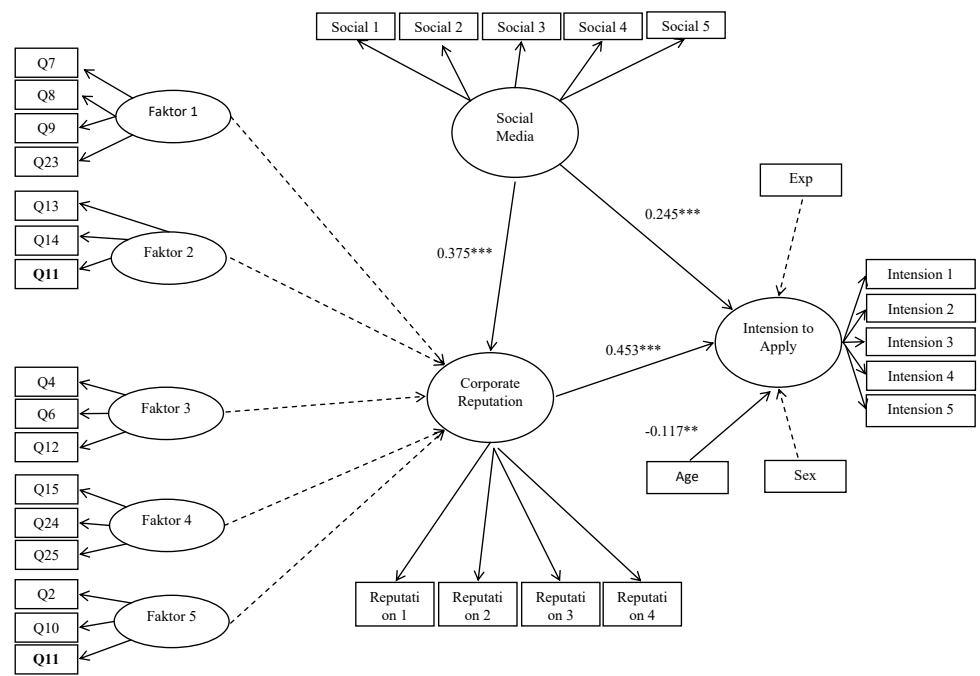

Fig. 3 - Overall results for the data set of students of economics. Source: own research

\section{DISCUSSION}

We conducted a replication of the model of Sivertzen et al. (2013), which investigates relationships between employer attractiveness, corporate reputation, use of social media and intentions to apply for a job. The study has an employer branding perspective, therefore, it is understood as a working within the field of research into employer branding structure. The aim of the model was to identify essential factors when conducting employer branding campaigns in organizations. Our paper has been conducted as a replication with an extension (Hubbard \& Armstrong, 1994; Hubbard \& Vetter, 1996). The existing literature, mainly referred to as employer branding, has been concerned primarily with the identification of relevant elements of employer value proposition, while several authors have pointed out the need to focus on relative elements. Therefore, the research presented in this paper attempted to replicate a model by Sivertzen et al. (2013) which investigates factors regarding employer branding strategies as well as verifies whether the predominant view of relevant elements might be considered inadequate. In order to replicate the model correctly, we formed our version as closely to the original as possible, and as a different factor of the model validation a particular industry was chosen. The original study researched data collected from the engineering industry, therefore, we decided to collect data from the information technology industry along with the economics \& business industry, each of which would be described first individually. First, the validation of employer attractiveness (EmpAt) scale was conducted. Second, the hypothesis from a proposed model was tested in order to contribute to the research of employer branding and its structure.

Students of IT: Based on our data from their responses, the dimensions in EmpAt have altered. After our analysis, five dimensions were constructed based on different related indicators as compared to Berthon's original scale. As the first step in validating EmpAt scale, different dimensions were constructed in the model of Sivertzen et al.. Second, hypothesis 1 was partly con- 
firmed, with hypotheses 2,3 and 4 confirmed as well. Our findings show that Factor 1, labelled as work environment, has a negative relation with corporate reputation, and Factor 2, labelled as progressive company, has a positive relation with corporate reputation. The work environment dimension contains seven indicators (e.g. having a good relationship with supervisors/ colleagues). The progressive company dimension contains four indicators (e.g. humanitarian organization; the organization produces high-quality products or services). The relation between the use of social media and corporate reputation, the use of social media with the intentions to apply for a job, and the relation between corporate reputation and intentions to apply for a job were confirmed.

Students of economics: Based on our data from the responses, the dimensions in EmpAt have altered. After the analysis, five dimensions were constructed with different related indicators as compared to Berthon's original scale. As the first step in validating the EmpAt scale, different dimensions were constructed in the model of Sivertzen et al. model. Second, hypothesis 1 was not confirmed, however, with hypotheses 2,3 and 4 confirmed. i.e. no relation between employer attractiveness and corporate reputation was found based on the data from students of economics, a result which could be seen as controversial. Nevertheless, a relation does exist between the use of social media and corporate reputation, use of social media and intention to apply for a job, as well as the relation between corporate reputation and intention to apply for a job.

In the original paper, the authors attributed a change in the dimensions and related indicators only regarding the possibility of cultural differences between Australia and Norway and other countries where researchers worked with the scale (Hewapattu Arachchige \& Robertson, 2012; Roy, 2008). However, as we collected two sets of data, we could compare two different results from two different industries within the same culture. During the validation of EmpAt scale, not only did the dimensions differ from other researches validating EmpAt scale, but the results were also different between the two data sets collected for this replication with extension. After the analysis, five dimensions were constructed with different related indicators. Therefore, the differences between the results could be explained by other aspects related to the research. It can be expected that the importance of particular indicators of employer attractiveness could be shown by the different needs of the potential employees, i.e. students. In this case, the disparities were not only caused by cultural differences, as an original study suggested. Therefore, the results indicate that the current predominant view of employer branding literature, focusing on the identification of relevant elements of the employer value proposition, might be considered inadequate.

The differences in results could therefore be explained by the main assumption of basic marketing practices that the needs of individuals vary (Kotler \& Keller, 2016; Malcolm \& Ian, 2004). Therefore, the suggestions to focus on relative elements (Babíková, 2019; Theurer et al., 2018) might prove to create successful future work in the field of human resource marketing. As different groups of consumers have different needs and wants, marketers can define multiple segments in order to meet each segment's needs effectively and profitably. Segmentation splits customers into different groups with similar needs by geographic, demographic, socio-economic and other factors (Kotler \& Armstrong, 1994). In this case, we could expect that a group of engineering students and a group of IT students are related to employer attractiveness internally regarding their needs and interests, which are heterogeneous to each other. Based on their needs and interests, the relation of particular indicators and dimensions to corporate reputation can be perceived differently. In a group of students of economics, no relation between a given 
dimension and corporate reputation has been confirmed. This could mean that the group of students of economics could be internally heterogeneous, and thus other factors should be used to segment this group into homogenous categories. Therefore, we assume that in the case of the segmentation of potential employees into homogenous groups by more factors, the results inside the group would be statistically stronger than the results coming from the industry segmentation only.

\section{CONCLUSION}

Our replication of the model of Sivertzen et al. (2013) aimed to provide additional evidence regarding the factors which contribute the most to structures of employer branding. The model proposed four hypotheses which described possible relationships between four constructs, i.e. the relationship between employer attractiveness and corporate reputation, corporate reputation and intention to apply for a job, and relationships between social media and reputation, and social media and intentions to apply for a job, as a possible mediation variables. The replication was conducted as closely as possible to the original study, with data differing in the key dimension of industry. We collected data from economic and business along with the information technology industries. Our data should be of an equivalent quality as the original study; however, we attempted to collect a larger quantity of data sets. By performing the replication, we provided additional evidence that should help to build the knowledge of employer branding factors. Our replication put forth a view on the proposed model in different conditions, and therefore has contributed to the original results and their applicability in different consequences. Therefore, we suggest that future research might focus on fields of intersection between human resource management and marketing, which in turn might focus on proper segmentation of potential candidates and existing employees, which would conform the condition of creating internally homogeneous and externally heterogeneous segments. The focus on the segmentation process might open up a space to implement additional marketing practices and tools into the research of attracting candidates and retaining employees. Apart from the theoretical implications, these results might also imply practical implications. Recent scholars have proved that HRM practitioners recognize the differences among the needs of different groups of candidates and employees, with the most mentioned distinctions occurring among cultures or generations, and between genders. However, a deeper awareness and the subsequent implication of a segmentation process might lead to systematic work with these groups, which in turn might foster the deeper integration of marketing principles into business and human resource strategy.

\section{Acknowledgments}

This article is based upon a working paper Computer science students' perception of attractiveness of prospective employers: identifying the factors of attractiveness and the use of social media in the context of the Czech Republic, hosted on International Conference on Lifelong Education and Leadership (ICLEL) 2017 in Porto and was created as a part of the research project "Talent management and organizational diversity" (MUNI/0817/2017) at the Masaryk University, Brno.

\section{References}

1. Ambler, T., \& Barrow, S. (1996). The employer brand. Journal of Brand Management, 4(3), 185-206. https://doi.org/10.1057/bm.1996.42. 
2. Andrews, K. R. (1971). The concept of corporate strategy. Homewood, Ill: R. D. Irwin.

3. Armstrong, M., \& Taylor, S. (2014). Armstrong's handbook of buman resource management practice (13th Edition). Philadelphia, PA: Kogan Page Ltd.

4. Babíková, K. (2019). Corporate marketing in international talent management (Dissertation Thesis). Masaryk University, Porto, Portugal.

5. Backhaus, K., \& Tikoo, S. (2004). Conceptualizing and researching employer branding. Career Development International, 9(5), 501-517. https://doi.org/10.1108/13620430410550754.

6. Barney, J. B. (1991). Firm Resources and Sustained Competitive Advantage. Journal of Management, 17(1), 99-120. https://doi.org/10.1177/014920639101700108.

7. Barney, J. B., \& Wright, P. M. (1998). On becoming a strategic partner: The role of human resources in gaining competitive advantage. Human Resource Management, 37(1), 31-46. https://doi.org/10.1002/(SICI)1099-050X(199821)37:1<31::AID-HRM4>3.0.CO;2-W.

8. Bergeron, C. (2004). Build a talent strategy to achieve your desired business results. Handbook of Business Strategy, 5(1), 133-140. https://doi.org/10.1108/10775730410494206.

9. Berthon, P., Ewing, M., \& Hah, L. L. (2005). Captivating company: dimensions of attractiveness in employer branding. International Journal of Advertising, 24(2), 151-172. https://doi.org/10.1080/02650487.2005.11072912.

10. Borstorff, P. C., Marker, M. B., \& Bennett, D. S. (2005). Online Recruitment: Attitudes and Behaviors of Job Seekers. Journal of Strategic E-Commerce, 5(2), 1-24.

11. Bowling, A. (2005). Mode of questionnaire administration can have serious effects on data quality. Journal of Public Health, 27(3), 281-291. https://doi.org/10.1093/pubmed/fdi031.

12. Boxall, P. (1996). The Strategic Hrm Debate and the Resource-Based View of the Firm. Human Resource Management Journal, 6(3), 59-75. https://doi.org/10.1111/j.1748-8583.1996. tb00412.x.

13. Cable, D. M., \& Turban, D. B. (2001). Establishing the dimensions, sources and value of job seekers' employer knowledge during recruitment. In Research in personnel and human resources management. Vol. 20. Retrieved from http://www.emeraldinsight.com/0742-7301/20.

14. Cappelli, P. (2001). Making the most of on-line recruiting. Harvard Business Review, 79(3), 139-146, 166.

15. Cascio, W. F., \& Graham, B. Z. (2016). New Strategic Role for HR: Leading the EmployerBranding Process. Organization Management Journal, 13(4), 182-192. https://doi.org/10.1080/1 5416518.2016.1244640.

16. Chauhan, R., Buckley, R., \& Harvey, M. (2013). Facebook and personnel selection: What's the big deal? Organizational Dynamics. http://dx.doi.org/10.1016/j.orgdyn.2013.03.006.

17. Collings, C. J., \& Kanar, A. M. (2013). Employer Brand Equity and Recruitment Research. In Oxford Library of Psychology. The Oxford Handbook of Recruitment.

18. Collins, C. J., \& Stevens, C. K. (2002). The relationship between early recruitment-related activities and the application decisions of new labor-market entrants: a brand equity 
approach to recruitment. Journal of applied psychology, 87(6), 1121.

19. Daniel, R. G., \& José, N. (2010). Employer Branding Constrains Applicants' Job Seeking Behaviour? Revista de Psicología del Trabajo y de Las Organizaciones, 26(3), 223-234. https://doi. org/10.5093/tr2010v26n3a6.

20. Edwards, M. R. (2009). An integrative review of employer branding and OB theory. Personnel Review, 39(1), 5-23. https://doi.org/10.1108/00483481011012809.

21. Ethiraj, S. K., Gambardella, A., \& Helfat, C. E. (2016). Replication in strategic management: Replication in Strategic Management. Strategic Management Journal, 37(11), 2191-2192. https://doi.org/10.1002/smj.2581.

22. Fisher, R., McPhail, R., You, E., \& Ash, M. (2014). Using social media to recruit global supply chain managers. International Journal of Physical Distribution \& Logistics Management, 44(8/9), 635-645. https://doi.org/10.1108/IJPDLM-07-2013-0179.

23. Foster, C., Punjaisri, K., \& Cheng, R. (2010). Exploring the relationship between corporate, internal and employer branding. Journal of Product \& Brand Management, 19(6), 401-409. https://doi.org/10.1108/10610421011085712.

24. Gatewood, R. D., Feild, H. S., \& Barrick, M. R. (2011). Human resource selection (7th ed). Mason, $\mathrm{OH}$ : South-Western, Cengage Learning.

25. Guthridge, M., Komm, A. B., \& Lawson, E. (2008). Making talent a strategic priority. McKinsey Quarterly, 1, 49-59.

26. Harzing, A.-W. (2016). Why replication studies are essential: learning from failure and success. Cross Cultural \& Strategic Management, 23(4), 563-568. https://doi.org/10.1108/ CCSM-07-2016-0133

27. Hepburn, S. (2005). Creating a winning employer reputation. Strategic HR Review, 4(4), 20-23. https://doi.org/10.1108/14754390580000802.

28. Arachchige, B. J., \& Robertson, A. (2011). Business Student Perceptions of a Preferred Employer: A Study Identifying Determinants of Employer Branding. IUP Journal of Brand Management, 8(3).

29. Highhouse, S., Lievens, F., \& Sinar, E. F. (2003). Measuring Attraction to Organizations. Educational and Psychological Measurement, 63(6), 986-1001. https://doi.org/10.1177/001316440 3258403 .

30. Horn, I. S., Taros, T., Dirkes, S., Hüer, L., Rose, M., Tietmeyer, R., \& Constantinides, E. (2015). Business reputation and social media: A primer on threats and responses. Journal of Direct, Data and Digital Marketing Practice, 16(3), 193-208. https://doi.org/10.1057/ dddmp.2015.1.

31. Hu, L., \& Bentler, P. M. (1999). Cutoff criteria for fit indexes in covariance structure analysis: Conventional criteria versus new alternatives. Structural Equation Modeling: A Multidisciplinary Journal, 6(1), 1-55. https://doi.org/10.1080/10705519909540118.

32. Hubbard, R., \& Armstrong, J. S. (1994). Replications and extensions in marketing: Rarely published but quite contrary. International Journal of Research in Marketing, 11(3), 233-248. 
https://doi.org/10.1016/0167-8116(94)90003-5.

33. Hubbard, R., \& Vetter, D. E. (1996). An empirical comparison of published replication research in accounting, economics, finance, management, and marketing. Journal of Business Research, 35(2), 153-164. https://doi.org/10.1016/0148-2963(95)00084-4.

34. Hubbard, R., Vetter, D. E., \& Little, E. L. (1998). Replication in Strategic Management: Scientific Testing for Validity, Generalizability, and Usefulness. Strategic Management Journal, 19(3), 243-254.

35. Kotler, P., \& Armstrong, G. (1994). Principles of marketing (Sixth edition). In The Prentice Hall Series in Marketing (Sixth edition). Englewood Cliffs, New Jersey: Prentice Hall.

36. Kotler, P., \& Keller, K. L. (2016). Marketing management (15 [edition]). Boston: Pearson.

37. Lievens, F., Van Hoye, G., \& Anseel, F. (2007). Organizational identity and employer image: Towards a unifying framework. British Journal of Management, 18, 45-59. https://doi. $\operatorname{org} / 10.1111 /$ j.1467-8551.2007.00525.x.

38. Mahroum, S. (2000). Highly skilled globetrotters: mapping the international migration of human capital. R\&D Management, 30(1), 23-32. https://doi.org/10.1111/1467-9310.00154.

39. Malcolm, M., \& Ian, D. (2004). Market Segmentation: How to Do It and How to Profit from It, Revised 4th Edition. Retrieved October 4, 2018, from Wiley.com website: https:// www.wiley.com/en-us/Market+Segmentation $\% 3 \mathrm{~A}+\mathrm{How}+$ to + Do+It+and+How + to + Profi $\mathrm{t}+$ from $+\mathrm{It} \% 2 \mathrm{C}+$ Revised+4th+Edition-p-9781118432679.

40. Penrose, E. T. (1959). The Theory of the Growth of the Firm. Oxford: Blackwell.

41. Roy, S. K. (2008). Identifying the dimensions of attractiveness of an employer brand in the Indian context. South Asian Journal of Management, 15, 110-130.

42. Shaw, J. D., \& Delery, J. E. (2001). The strategic management of people in work organizations: Review, synthesis, and extension. In Research in Personnel and Human Resources Management, Vol. 20, 165-197. https://doi.org/10.1016/S0742-7301(01)20003-6.

43. Singh, K. (2003). Increasing Replication for Knowledge Accumulation in Strategy Research. Journal of Management, 29(4), 533-549. https://doi.org/10.1016/S01492063(03)00024-2.

44. Sivertzen, A.-M., Nilsen, E. R., \& Olafsen, A. H. (2013). Employer branding: employer attractiveness and the use of social media. Journal of Product \& Brand Management, 22(7), 473-483. https://doi.org/10.1108/JPBM-09-2013-0393.

45. Theurer, C. P., Tumasjan, A., Welpe, I. M., \& Lievens, F. (2018). Employer Branding: A Brand Equity-based Literature Review and Research Agenda. International Journal of Management Reviews, 20(1), 155-179. https://doi.org/10.1111/ijmr.12121.

46. Turban, D. B. (2001). Organizational Attractiveness as an Employer on College Campuses: An Examination of the Applicant Population. Journal of Vocational Behavior, 58(2), 293-312. https://doi.org/10.1006/jvbe.2000.1765.

47. Turban, D. B., Forret, M. L., \& Hendrickson, C. L. (1998). Applicant Attraction to Firms: Influences of Organization Reputation, Job and Organizational Attributes, and Recruiter Behaviors. Journal of Vocational Behavior, 52(1), 24-44. https://doi.org/10.1006/ 
jvbe.1996.1555.

48. Universum. (2017). Czech Republic's Most Attractive Employers. Retrieved from http://www. universumczech.com/pruzkum/.

49. van Witteloostuijn, A. (2016). What happened to Popperian falsification? Publishing neutral and negative findings: Moving away from biased publication practices. Cross Cultural \& Strategic Management, 23(3), 481-508. https://doi.org/10.1108/CCSM-03-2016-0084.

50. Weigelt, K., \& Camerer, C. (1988). Reputation and Corporate Strategy: A Review of Recent Theory and Applications. Strategic Management Journal, 9(5), 443-454.

51. Wernerfelt, B. (1984). A resource-based view of the firm. Strategic Management Journal, 5(2), 171-180. https://doi.org/10.1002/smj.4250050207.

52. Wright, P. M., Dunford, B. B., \& Snell, S. A. (2001). Human resources and the resource based view of the firm. Journal of Management, 27(6), 701-721. https://doi.org/10.1177/01492 0630102700607.

\section{Contact information}

Ing. Kristina Babikova

Masaryk University

Faculty of Economics and Administration

Department of Corporate Economy

Czech Republic

E-mail:kristina.babikova@econ.muni.cz

ORCID: https://orcid.org/0000-0001-9470-3513

Ing. Mgr. Jakub Bucek

Masaryk University

Faculty of Economics and Administration

Department of Corporate Economy

Czech Republic

E-mail:jakub.bucek@econ.muni.cz. 